\title{
小学校高学年を対象としたサッカー授業におけるミニゲームの 体力つくりからみた負荷特性：コートの広さの相違による影響
}

\begin{abstract}
津田 龍佑 ${ }^{1)}$ 鈴木 宏哉 ${ }^{2)}$ 齊藤 一彦 ${ }^{3)}$ 木越 清信 ${ }^{4)}$
TSUDA Ryosuke ${ }^{1}$, SUZUKI Koya ${ }^{2}$, SAITO Kazuhiko ${ }^{3}$ and KIGOSHI Kiyonobu ${ }^{4}$ : Load characteristics of small-sided soccer games as a regular curriculum activity for improving the physical fitness of upper grade elementary school children: effect of differences in pitch area. Japan J. Phys. Educ. Hlth. Sport Sci.
\end{abstract}

\begin{abstract}
This study investigated the effects of a change in pitch area on the load characteristics of smallsided soccer games (4vs4 and 3vs3) as a regular curriculum activity for upper grade elementary school children, focusing on improvement in physical fitness.

Sixteen children participated in 2 types of $4 \mathrm{vs} 4$ small-sided games with a change in pitch area: Game 1-1 "large pitch" ( $30 \mathrm{~m}$ length $\times 20 \mathrm{~m}$ width) and Game 1-2 "small pitch" ( $20 \mathrm{~m}$ length $\times 15 \mathrm{~m}$ width). In addition, 12 children participated in 2 types of $3 \mathrm{vs} 3$ small-sided games: Game 2-1 "large pitch" ( $30 \mathrm{~m}$ length $\times 20 \mathrm{~m}$ width) and Game $2-2$ "small pitch" ( $20 \mathrm{~m}$ length $\times 15 \mathrm{~m}$ width).
\end{abstract}

The ratio of the appearance time of each movement speed (low speed: $0-5.9 \mathrm{~km} / \mathrm{h}$, moderate to high speed: 6.0 $23.0 \mathrm{~km} / \mathrm{h}$ ) and the total movement distance were measured using GNSS tracking technology (Fieldwiz, ASI). Questionnaires on technique and tactics, physical fitness and psychological aspects were then conducted after each game.

The main results were as follows.

1) The total movement distance during large pitch games was significantly greater than that of small pitch games $(p<0.05)$.

2) The ratio of the appearance time of moderate and high speed $(6-23 \mathrm{~km} / \mathrm{h})$ during large pitch games was significantly greater than that of small pitch games $(p<0.05)$.

3) Over $80 \%$ of the subjects indicated a positive response in the questionnaire from the aspect of interest.

4) There was a significantly positive correlation between the total movement distance and the total physical fitness score in $4 \mathrm{vs} 4$ games $(p<0.05)$. However, no significant correlation was observed in $3 \mathrm{vs} 3$ games.

These results suggest that small-sided soccer games with a change in pitch area might be useful for improvement of physical fitness, and that it would be possible even for children with different fitness levels to have equal opportunities for participating in $3 \mathrm{vs} 3$ games.

Key words : Global Navigation Satellite System (GNSS), amount of physical activity, goal type ball games キーワード : 全球測位衛星システム, 身体活動量, ゴール型ボールゲーム

1）金沢医科大学一般教育機構

干 920-0293 石川県河北郡内灘町大学 1-1

2) 順天堂大学スポーツ健康科学部

干 270-1695 千葉県印西市平賀学園台 1-1

3）広島大学大学院人間社会科学研究科

干 739-8524 広島県東広島市鏡山 1-1-1

4) 筑波大学体育系

干 305-8574 茨城県つくば市天王台 1-1-1

連絡先 津田龍佑
1. General Education Department Faculty, Kanazawa Medical University

1-1 Daigaku, Uchinada-machi, Kahoku-gun, Ishikawa 9200293

2. Faculty of Health and Sports Science, Juntendo University 1-1 Hirakagakuendai, Inzai, Chiba 270-1695

3. Graduate School of Humanities and Social Sciences, Hiroshima University

1-1-1 Kagamiyama Higashihiroshima, Hiroshima 739-8524

4. Faculty of Health and Sport Sciences, University of Tsukuba 1-1-1 Tennodai, Tsukuba, Ibaraki 305-8574

Corresponding author r-tsuda@kanazawa-med.ac.jp 


\section{I 緒 言}

現行の学習指導要領の成果と課題をみると, 運 動する子どもとそうでない子どもの二極化がみら れること, 子どもの体力は改善傾向にあるが, 体 カレベルの高かった昭和 60 年（1985 年）頃と比 較すると依然として低いこと, などが指摘されて いる（文部科学省，2017）。これらのことを踏ま えて, 学校体育では体つくり運動系の領域以外に おいても子ども達の体力向上を図ることが求めら れている（文部科学省，2017）。このことに関連 して, 令和元年度の全国体力・運動能力, 運動習 慣等調査の結果（スポーツ庁，2019）をみると, 小学校 5 年生の場合, 体育以外の 1 週間の総運動 時間が 60 分に満たない児童が男子では $7.6 \%$ ，女 子では $13 \%$ に上っている. しかし，どんなに 1 週間の総運動時間が少ない子どもであっても体育 の時間だけは必ず運動機会が保証されているた め，体育の時間を充実させていくことがすべての 子どもの体力向上にとって重要である.

体力向上を目的とした体育授業研究を概観する と，次のような論文がみられる。まず，個人的技 能が中心となるスポーツを対象にした研究とし て土肥ほか（2004）, 加藤ほか (2000), 尾縣ほか （2001）などがあげられる.

加藤ほか（2000）は，体育授業における疾走能 力の練習効果を小学校 6 年生を対象に検討した. その結果, 疾走能力が向上し、その背景としてス タートダッシュに打ける加速局面とゴール付近で の速度持続局面のピッチやストライドの改善を報 告した. 土肥ほか（2004）は，体育授業における 走り幅跳びの練習効果を小学校 6 年生を対象に検 討した. その結果, 男女ともに跳躍距離を伸ばし, その背景として最適な助走距離を理解したことな どがあったことを報告した。尾縣ほか (2001) は, 小学校 $2 \cdot 3$ 年生を対象とした投能力を改善する ための学習プログラムを開発し, その有効性を検 証した。 その結果, 男女ともに遠投距離が向上し たこと，男子において遠投能力水準が低いものほ ど大きな向上が認められたことを報告した。これ
らの研究は, 小学校体育授業の基礎的な運動技能 の中でも代表的な動きである走・跳・投（日本学 術会議, 2017）の学習効果を授業研究をとおして 検証したものである.

一方, 対人的・集団的技能が中心となるスポ ーツを対象にした研究として Tsuda et al., (2007), 津田ほか（2013，2014）などがあげられる.

Tsuda et al., (2007) は, コートの広さ・人数の 相違がサッカーのミニゲームの体力つくりからみ た負荷特性に及ぼす影響を, 中学校男子生徒を対 象に検討した. その結果, 少人数のゲームは多人 数のゲームと比較して技術の習得が期待でき，ま た 1 人あたりのコートが広いゲームは狭いゲーム と比較して, 無酸素性パワーの向上が期待できる ことを報告している．また, 津田ほか（2013）は, コートの広さ・人数を工夫したサッカーの 4 対 4 のゲームを単元計画に組み込んだ授業の効果を, 中学校男子生徒を対象に検討した. その結果, コ 一トの広さに関わらず加速・減速あるいは方向変 換という動きの中で発揮される走力を高めること ができることを報告した.さらに,津田ほか(2014) は, コートの広さ・人数を工夫したサッカーの 8 対 8 のゲームを単元計画の中に組み込んだ授業の 効果を, 中学校男子生徒を対象に検討した. その 結果, コートが広いゲームでは加速・減速あるい は方向変換という動きの中で発揮される走力を高 めることができることを報告した，上述の研究 は, アマチュアサッカー選手を対象に, 少人数の ゲームに焦点を当て，それぞれの人数のゲームに おけるコートの広さを変えることにより，心拍 数, 血中乳酸濃度, 走行距離などの生理的応答が 異なるという知見（Hill-Hass et al., 2011）を中学 校体育授業サッカーに応用したものである. しか し, Hill-Hass et al.（2011）の研究では, ゲーム中 の走行距離を算出しているものの, 速度の観点か らは分析を行っていない. また, 津田ほか（2013, 2014）の研究では対象者が中学校男子生徒に限定 されており, 小学校体育授業については明らかに していない. 近年では, 1 週間に 3 日以上運動・ スポーツをする子どもとそうでない子どもの体力 差が拡大していることが示されており（スポーツ 
庁，2016）, 日常的に運動しない子どもに対する 体育授業での運動量確保の手立てが以前よりも重 要になってきた. 特に,「高学年の児童は体力に ついての認識が高まってくることを踏まえ, 体力 の重要性を理解するとともに, 各種の運動の楽し さを味わい, 活発に運動を行っていく中で, 各種 の運動の基本となる様々な技能を身につけ, 結果 として体力の向上を図ることを目指す」（文部科 学省, 2017, p.113) ことが小学校学習指導要領 解説の第 5 学年及び第 6 学年の目標に明示されて いる．このことを考慮すると，体力つくりに配慮 した授業が重要になると考えられる。

運動領域におけるボール運動・サッカーは子ど もに人気の高い運動であるが, 指導経験の浅い先 生やクラス内で子ども達に技能差があるような時 に授業が難しいことも指摘されている（日本サッ カー協会, 2017). 小学校高学年におけるボール 運動の授業を展開する際には，ルールや形式が一 般化されたゲームを児童の発達段階を踏まえ, 実 態に応じたボール操作を行うことができ，プレイ ヤーの人数, コートの広さ, ネットの高さ, 塁間 の距離, プレイ上の制限, ボールその他の運動用 具や設備などを修正し，児童が取り組みやすいよ うに工夫することが求められている(文部科学省, 2017)。これまでのボール運動の体育授業研究を みると，どのようなゲームの工夫が技能の向上に つながるのかといった点について検証されてい るが (中島ほか, 2017 ; 鬼澤ほか, 2007, 2008, 2012), 技能の習得の結果としての体力向上の観 点からは十分に検証されていない.このことを 考慮すると，小学校の体育授業を対象にどのよう な工夫が子どもの体力向上に寄与するのかを検証 する試みは極めて重要であると考えられる.

一方, 最近では Global Navigation Satellite System（GNSS，以下「GPS」と略す）を活用 したトレーニングやゲーム分析が行われている (Cunniffe et al., 2009 ; 古川, 2013). しかし, そ のほとんどは競技現場を対象としたものであり， 学校現場を対象としたものは中学生に焦点を当 てた中西ほか (2018）の報告がみられるのみであ る.ただし, 中西ほか（2018）の研究はサッカー
のゲームを身体活動量の観点から検討するに留ま っており，生徒がゲームをどのように評価したの かについて検討していない。なお, ゴール型・サ ッカーでは，ゲームを実施した結果として，巧 緻性，敏捷性，スピード，全身持久力などの体 力要素が高まることが期待される（文部科学省, 2017). 本研究ではこれらの体力要素のうち, ス ピードおよび全身持久力に焦点を当てる. その理 由は, GPSによって客観的に測定された走行距 離や各速度の走行距離からみた刺激が繰り返し与 えられることにより，スピードや全身持久力の向 上が期待できるからである.

そこで本研究では, 小学校体育サッカーの授業 で推奨されている 4 対 4 および 3 対 3 のミニゲー ム（日本サッカー協会，2017）に焦点を当て, コ ートの広さの相違の観点から体力つくりからみた 負荷特性を小学校高学年を対象に検討することを 目的とした。なお，体力つくりに配慮した結果， 児童にどのように受け止められたのかを把握する ため, 本研究では児童の主観的評価も含めて検討 することとした.

\section{II 方 法}

\section{1. 対象者および実験運動}

研究対象とした体育授業は, 2019 年 9 月 18 日 から 26 日にかけて実施された 3 時間のうち， 2 時間目であった。授業の中で各種ゲームを実施す ることを依頼した結果，カリキュラムの都合で上 述の設定となった．授業のねらいは練習の仕方を 知ること, およびそれらの練習を通してサッカー の技能を高めることであった. 各時間の主な内容 は，1時間目はサッカーの特性および GPS につ いて知ること, 2 時間目は各種ゲームを実施する こと，3時間目は GPS により得られたデータか らゲームを振り返ることであった. 2 時間目には, 授業の最初にねらいの確認と準備運動を，次にミ ニゲームを, 最後に学習のまとめと整理運動を行 わせた.

上述の目的を達成するために, 本研究では以下 の 2 つの実験を実施した. 実験 1 では 4 対 4 , 実 
験 2 では 3 対 3 にそれぞれ焦点をあて，コート の広さの相違がゲーム中の負荷特性に及ぼす影響 を検討した．対象者は公立 A 小学校に在籍する 6 年生の児童 28 名（男子 13 名, 女子 15 名）であ り，4 対 4 を実施する群と 3 対 3 を実施する群に 分類した．なお，4対 4 に参加する児童 16 名と 3 対 3 に参加する児童 12 名との間には体力合計点 からみて有意差はみられなかった。実験を開始す るにあたり, 学校長, 担当教諭（学年主任, クラ ス担任）およびすべての対象者および保護者に本 研究の目的，方法および安全性などを十分に説明 し，実験参加に対する同意を得た。本研究は順天 堂大学スポーツ健康科学部研究等倫理委員会の承 認（承認番号：28-17）を得て実施した.

\section{1 実験 $1: 4$ 対 4 の場合}

4 対 4 のゲームにおいて, 広いコートと狭いコ ートの 2 種類を準備した。この理由として，611 歳の段階において 4 対 4 では $30 \mathrm{~m} \times 20 \mathrm{~m}$ のコ ートがめやすとなること（スピンドラー，2000）, Hill-Hass et al.（2011）の研究では 4 対 4 では $30 \mathrm{~m} \times 20 \mathrm{~m}$ のコートの広さに着目して生理的応 答を検証していること，などがあげられる.

ゲーム 1-1：コートの広さ：縦 $30 \mathrm{~m} \times$ 横 $20 \mathrm{~m}$, 人数 : 4 対 4

ゲーム 1-2：コートの広さ：縦 $20 \mathrm{~m} \times$ 横 $15 \mathrm{~m}$, 人数: 4 対 4

対象者は公立 A 小学校に在籍する 6 年生の児 童 16 名（男子 8 名，女子 8 名）であった。これ らの児童のうち, サッカー少年団に在籍している 者はいなかった。 4 対 4 のゲームを行わせるため に，児童 16 名を 4 人 $\times 4$ グループ $(\mathrm{A} ・ \mathrm{~B} ・ \mathrm{C} \cdot$ $\mathrm{D}$ グループ）に分類した. 順序効果を相殺するた めに, $\mathrm{A} ・ \mathrm{~B}$ グループは最初の 3 分は広いコート, 次の 3 分は狭いコートでプレーさせた。一方, C・ $\mathrm{D}$ グループは最初の 3 分は狭いコート, 次の 3 分 は広いコートでプレーさせた。ゲーム間には 5 分 の休㕰時間を設けた。ゲーム時間は小学校体育の 場合には 1 試合の時間は 2-3 分程度が適当であ ること（日本サッカー協会，2017）から，各ゲー ム 3 分とした。ボールは柔らかいボール（モルテ
ン社製，ソフトスポンジボール）を用いた。ゴ ールはコーンゴールを用い，その間隔は $3 \mathrm{~m}$ とし た。ルールは次の通りとした。 (1)キックオフはゲ 一ム開始のみとする。(2)シュートが決まったあと はゴールキックからリスタートする. (3)ボールが サイドから出た場合はキックインとする. (4)ファ ールがあったらすべて直接フリーキックとする.

(5)オフサイドはなし，6へペナルティキックはな し、ゲームの課題は，パスをつないでボールを進 めることとした．なお，プレー機会を確保するた め,コート周辺に代わりのボールを用意しておき， コート外にボールが出た場合にすぐにプレーを再 開できるようにした.

\section{2 実験 $2: 3$ 対 3 の場合}

3 対 3 のゲームに打いて，広いコートと狭いコ ートの 2 種類を準備した。この理由として，小 学校体育の段階において, 3 対 3 では $20 \mathrm{~m} \times 15 \mathrm{~m}$ のコートの広さがめやすとなること（日本サッカ 一協会, 2017), Hill-Hass et al. (2011）の研究で は 3 対 3 では $20 \mathrm{~m} \times 15 \mathrm{~m}$ のコートの広さに着目 して生理的応答を検証していること，などがあげ られる。

ゲーム 2-1：コートの広さ：縦 $30 \mathrm{~m} \times$ 横 $20 \mathrm{~m}$, 人数 $: 3$ 対 3

ゲーム 2-2：コートの広さ：縦 $20 \mathrm{~m} \times$ 横 $15 \mathrm{~m}$, 人数 : 3 対 3

対象者は実験 1 と同じ小学校に在籍する 6 年生 の児童 12 名（男子 5 名，女子 7 名）であった. これらの児童のうち, サッカー少年団に在籍する 者は 1 名のみであった. 3 対 3 のゲームを行わせ るために, 児童 12 名を 3 人 $\times 4$ グループ $(a \cdot b \cdot c \cdot$ d グループ）に分類した。 順序効果を相殺するた めに, $\mathrm{a} ・ \mathrm{~b}$ グループは最初の 3 分は広いコート, 次の 3 分は狭いコートでプレーささせた. 一方, c $\mathrm{d}$ グループは最初の 3 分は狭いコート, 次の 3 分 は広いコートでプレーさせた。ゲーム間の休息時 間，ゲーム時間，ボール，ルール，課題，試合の 早期再開方法については実験 1 と同様とした。 


\section{2. 測定項目および測定方法}

\section{1 ゲーム中の負荷特性 : 走行距離と各速度の走} 行距離

GPS（ASI 社製，Fieldwiz）を用いて，ゲー ム中の走行距離や各速度（0-5.9 km/h，6.0$14.9 \mathrm{~km} / \mathrm{h}, \quad 15.0-23.0 \mathrm{~km} / \mathrm{h})$ の走行距離を算出 した. 本研究では $0-5.9 \mathrm{~km} / \mathrm{h}$ を歩行（低強度）, 6.0 - $14.9 \mathrm{~km} / \mathrm{h}$ と 15.0 - $23.0 \mathrm{~km} / \mathrm{h}$ を合わせた 6.0 一 $23.0 \mathrm{~km} / \mathrm{h}$ をジョギングからスプリント（中・ 高強度）として扱った。 その理由は, 日本体育協 会（2015）は子どもの心身の健全な発達のために 「毎日 60 分以上の中・高強度の身体活動」を求め ているからである. また, 本研究では運動強度の 定義づけに際して, 以下の先行研究を参考にし た. 成人プロサッカー選手を対象にした研究では, 時速 $6 \mathrm{~km} / \mathrm{h}$ 末満をウォーキング， 6- $14.9 \mathrm{~km} / \mathrm{h}$ を 低強度のランニング, $15 \mathrm{~km} / \mathrm{h}$ 以上を高強度のラ ンニングとしている（Mohr et al., 2003）。 また 10 -12 歳の子どもを対象にした研究では 4.0 マイ ル $(6.4 \mathrm{~km} / \mathrm{h})$ のウォーキングは $5.2 \mathrm{Mets}$ (中強 度）に対応することが報告されている（Butte et al., 2018).

上背部にミニバックポケットが付いているチェ ストベストを装着させ，そのポケットに GPS 機 器本体を挿入して計測を実施した。 その後, ドッ キングステーションを利用して取得したデータを パソコンに移行し, 専用のウェブアプリケーショ ンを用いてデータを解析した。 なお, 本研究で使 用した GPS は, スイスサッカー協会をはじめ多 くの組織やクラブで活用されており, FIFA（国 際サッカー連盟）の公式戦で使用するために必要 な IMS 認定を取得している. GPS の装着の仕方 やそのねらいについては授業に先立って説明を行 った.

\section{2 ゲーム終了後の質問紙調査}

ゲーム終了後に技術・戦術面, 体力面, 心理面 から構成される質問紙調査を実施した。質問項目 は津田ほか（2013，2014）を参考にした。技術・ 戦術面はボールに関わる動きとボールを持たない 動き, 体力面はエネルギー系の体力要因とそれぞ
れ関連付けてゲームを評価する内容であった。心 理面は関心・意欲・態度からゲームを評価する内 容とした.これらの質問項目について児童に 5 件 法（まったくあてはまらない, あまりあてはまら ない, どちらでもない, あてはまる, よくあては まる）で回答させた.

\section{3 体カテスト}

2019 年の新体力テスト全 8 種目の合計点を算 出した. すなわち, 新体力テストの実施要項に 従って実施した測定結果をもとに，8種目の体力 合計点（80 点満点）を算出した（文部科学省, 2006).

\section{3. 統計処理}

ゲーム中の走行距離と各速度の走行距離の群間 （狭いコートと広いコート）差の検定には，対応 のある $\mathrm{t}$ 検定を用いた。また， 2 変数間の相関関 係(ゲーム中の総走行距離と体力テストの合計点) の算出にはピアソンの積率相関分析を用いた．統 計処理の有意性は危険率 $5 \%$ 未満で判定した。な お，データ処理には IBM SPSS statics ver. 25 を用 いた.

\section{III 結 果}

\section{4 対 4 の場合}

図 1 に，ゲーム中の総走行距離および各速度に おける走行距離を示した。 また資料 1 に, 個人ご とのデータを示した. ゲーム中の総走行距離（全

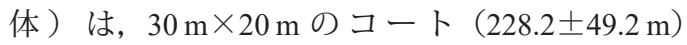
が $20 \mathrm{~m} \times 15 \mathrm{~m}$ のコート $(170.8 \pm 57.5 \mathrm{~m})$ と比較 して有意に高值を示した $(p<0.05)$. また, 低強 度の走行距離は両群間に有意差は認められなかっ たが, 中・高強度の走行距離は $30 \mathrm{~m} \times 20 \mathrm{~m}$ のコ ート (113.5 $557.2 \mathrm{~m})$ が $20 \mathrm{~m} \times 15 \mathrm{~m}$ のコート(57.7 $\pm 40.0 \mathrm{~m})$ と比較して有意に高值を示した（ $p<$ $0.05)$.

表 1 に, 4 対 4 のゲーム終了後の質問紙調査の 結果を示した。技術・戦術面の質問項目 1 （課題 達成）に対して肯定的な回答（あてはまる・よく 


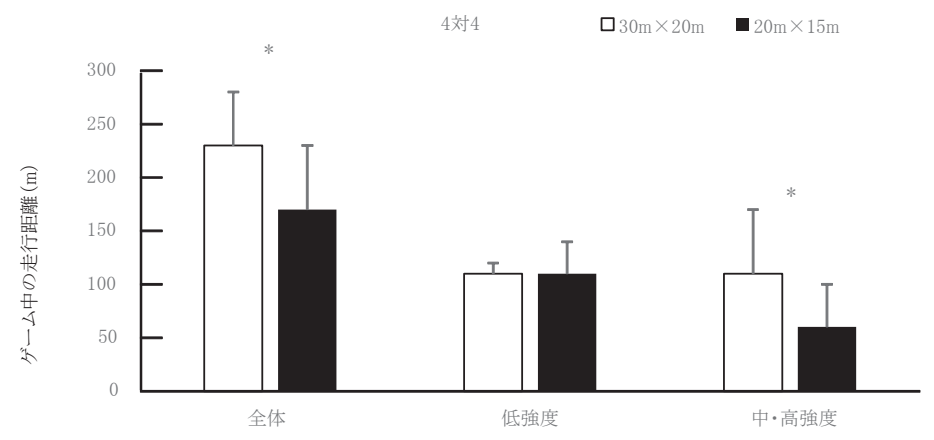

図 14 対 4 における総走行距離および各速度における走行距離

$* p<0.05$

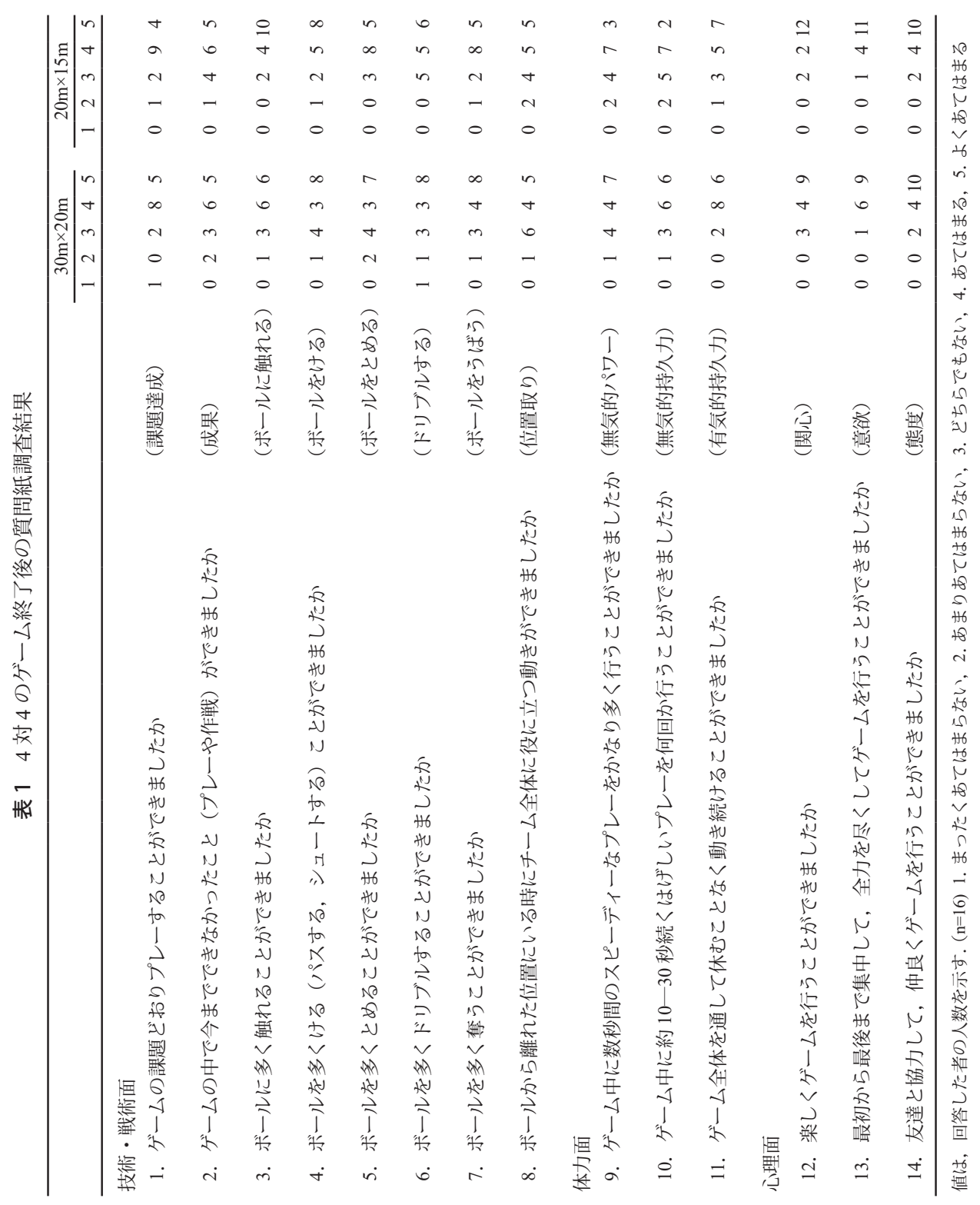


あてはまる）を示した児童の割合はいずれのゲー ムも $81 \%$ （13/16人）であった。体力面の質問 項目 10 （無気的持久力）に対して肯定的な回答 を示した児童の割合は $30 \mathrm{~m} \times 20 \mathrm{~m}$ のコートでは $75 \%$ (12/16 人), $20 \mathrm{~m} \times 15 \mathrm{~m}$ のコートでは $56 \%$ （9／16）であった。 心理面の質問項目 12 (関心） に対して肯定的な回答を示した児童の割合はいず れのゲームも 8 割を超えた $(30 \mathrm{~m} \times 20 \mathrm{~m}: 13 / 16$ 人 $=81 \%, 20 \mathrm{~m} \times 15 \mathrm{~m}: 14 / 16$ 人 $=88 \%)$.

図 2 に, 4 対 4 のゲーム中の総走行距離と体力 テストの合計点との関係を示した. コートの広さ に関わらず, 総走行距離（全体）と体力テストの 合計点との間に有意な正の相関関係(広いコート： $\mathrm{r}=0.49$, 狭いコート $: \mathrm{r}=0.52)$ が認められた $(p<$ $0.05)$.

\section{3 対 3 の場合}

図 3 に, ゲーム中の総走行距離および各速度に おける走行距離を示した。 また資料 2 に, 個人ご とのデータを示した. ゲーム中の総走行距離（全 体）は, $30 \mathrm{~m} \times 20 \mathrm{~m}$ のコート $(227.3 \pm 40.4 \mathrm{~m})$

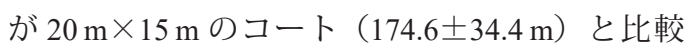
して有意に高值を示した $(p<0.05)$. また, 低強 度の走行距離は両群間に有意差は認められなかっ たが, 中・高強度の走行距離は $30 \mathrm{~m} \times 20 \mathrm{~m}$ のコ ート $(113.0 \pm 48.5 \mathrm{~m})$ が $20 \mathrm{~m} \times 15 \mathrm{~m}$ のコート $(55.5$ $\pm 34.5 \mathrm{~m})$ と比較して有意に高值を示した（ $p<$ $0.05)$.

表 2 に, 3 対 3 のゲーム終了後の質問紙調査の 結果を示した。技術・戦術面の質問項目 1（課 題達成）に対して肯定的な回答（あてはまる・ よくあてはまる）を示した児童の割合は $30 \mathrm{~m} \times$

4 対 $4,30 \mathrm{~m} \times 20 \mathrm{~m}$

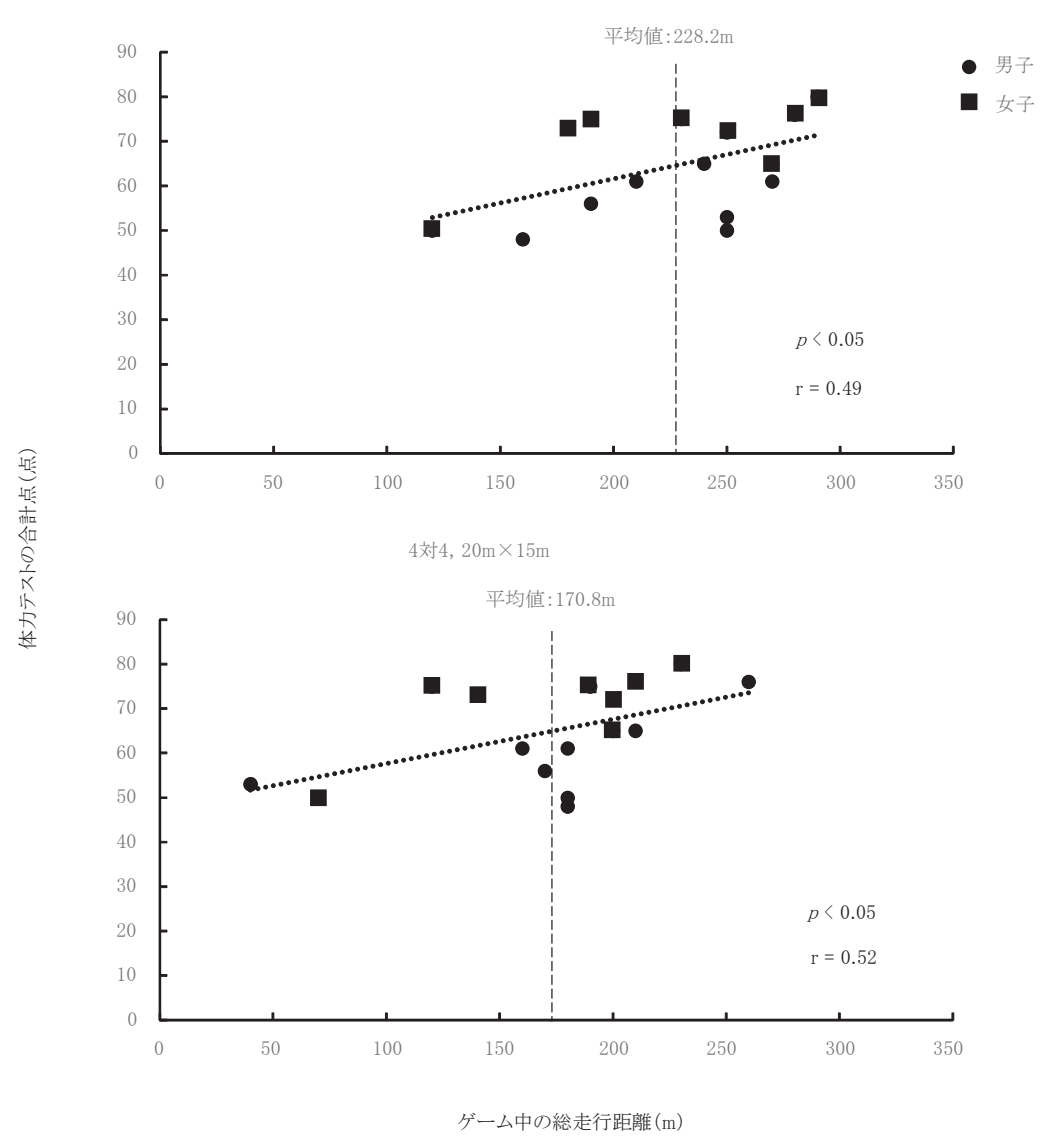

図 24 対 4 のゲーム中の総走行距離と体力テストの合計点との関係 


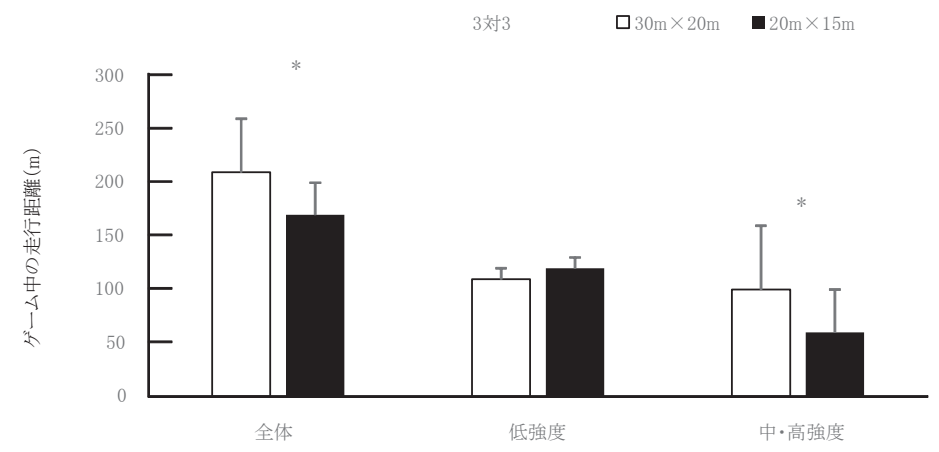

図 33 対 3 における総走行距離および各速度における走行距離 $* p<0.05$

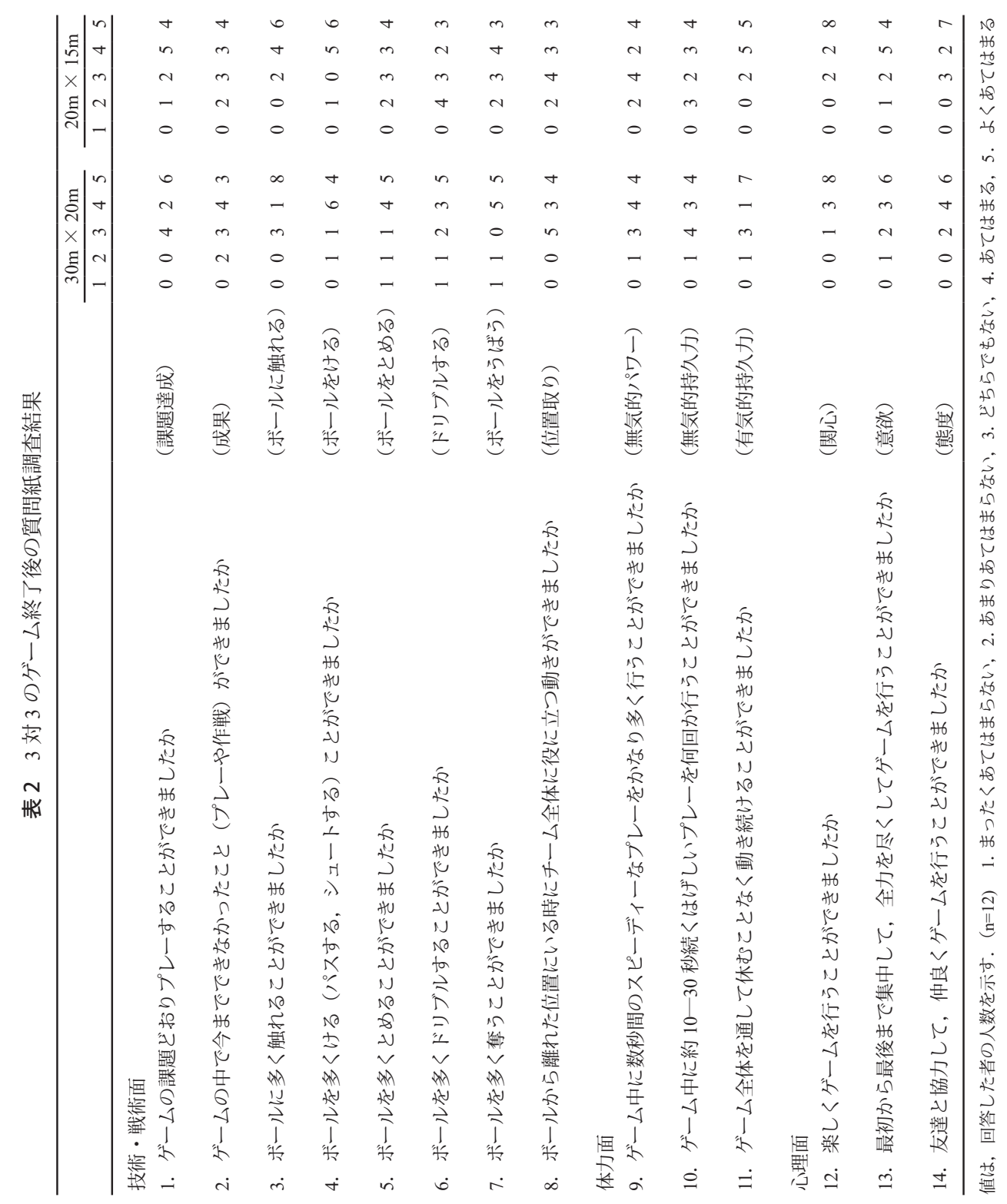


$20 \mathrm{~m}$ のコートでは $66 \%$ (8/ 12 人 $), 20 \mathrm{~m} \times 15 \mathrm{~m}$ のコートでは $75 \%$ （9/12人）であった. 体力面 の質問項目 9 (無気的パワー) に対して肯定的な 回答を示した児童の割合は $30 \mathrm{~m} \times 20 \mathrm{~m}$ のコート では $66 \%$ （8／12人), $20 \mathrm{~m} \times 15 \mathrm{~m}$ のコートでは $50 \%(6 / 12$ 人)であった. 心理面の質問項目 12 (関 心）に対して肯定的な回答を示した児童の割合は いずれのゲームも 8 割を超えた $(30 \mathrm{~m} \times 20 \mathrm{~m}: 11$ $/ 12$ 人 $=91 \%, 20 \mathrm{~m} \times 15 \mathrm{~m}: 10 / 12$ 人 $=83 \%)$.

図 4 に, 3 対 3 のゲーム中の総走行距離と体力 テストの合計点との関係を示した.コートの広さ に関わらず，総走行距離（全体）と体力テスト の合計点との間に有意な相関関係（広いコート： $r=0.22$ ，狭いコート $r=0.50 ）$ は認められなかっ た.

\section{IV 考察}

本研究では, 小学校体育サッカーの授業で推奨 されている 4 対 4 および 3 対 3 のミニゲームに焦 点を当て, コートの広さの相違の観点から体力つ くりからみた負荷特性を小学校高学年を対象に 検討することを目的とした. 多くの国々におい て, 子どもの身体活動ガイドラインが提案されて おり，いずれも心身の健康な発達のために「毎日 60 分以上の中・高強度の身体活動」を推奨して いる（日本体育協会，2015）。このように望まし い身体活動について, 量と強度の観点から整理さ れていることを踏まえて, 本研究でも量と強度の 観点から検討することにした.

3 対 $3,30 \mathrm{~m} \times 20 \mathrm{~m}$

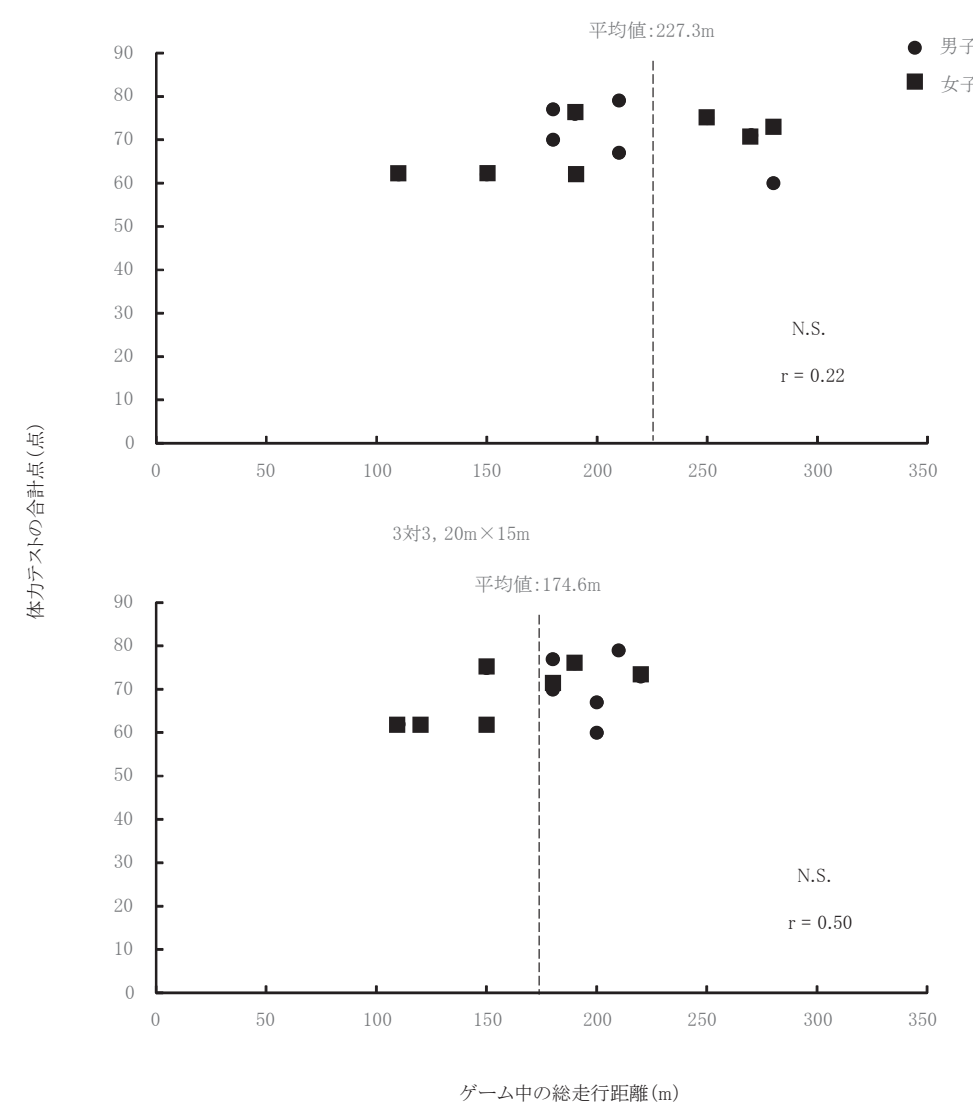

図 43 対 3 のゲーム中の総走行距離と体力テストの合計点との関係 
まず，ゲームの中でどのくらい動いていたのか について検討した. その結果，ゲーム中の総走行 距離（全体）は 4 対 4,3 対 3 のいずれの場合も $30 \mathrm{~m} \times 20 \mathrm{~m}$ コートが $20 \mathrm{~m} \times 15 \mathrm{~m}$ コートと比較し て有意に高值を示した（図 1, 図 3)。これまでア マチュアサッカー選手を対象に，コートの広さ・ 人数を工夫することにより身体活動量が増加する ことが報告されている（Hill-Hass et al., 2011）。本 研究の結果は, この知見を裏づけるものであり, 男女共習で行われ，運動が得意な子どもと苦手な 子どもが混在している小学校体育授業・サッカー を対象に検討した初めての研究である. 次に, 総 走行距離（全体）と体力テストの合計点との相関 関係について検討した．その結果，4対 4 ではコ 一トの広さに関わらず，両者の間に有意な正の相 関関係が認められた（図 2)。一方，3 対 3 ではコ 一トの広さに関わらず，両者の間に有意な相関関 係は認められなかった（図 4)。このことは，4 対 4 では体力が高い子どもほど活動量が多くなるの に対して，3 対 3 ではそのような傾向は認められ ないことを示すものである.この理由の 1 つとし て，ゲームの人数が少なくなると実質的に関わら ざるを得ないこと（日本サッカー協会，2017）が あげられる．すなわち，4 人チームのゲームでは 体力の低い子どもは体力の高い子どもと比べて活 動量が制限される可能性があるのに対して，3 人 チームのゲームでは体力の低い子どもであっても 体力の高い子どもと同等な活動量を保証される可 能性を示唆する結果であったといえる。なお，男 女別にみると， 4 対 4 ではコートの広さに関わら ず，8名中 5 名の女子が平均走行距離を上回った (図2). また, 3 対 3 ではコートの広さに関わらず, 7 名中 3 名の女子が平均走行距離を上回った（図 4). 本研究では, ボールに対する恐怖心を軽減す るために柔らかいボールを使用したことから，男 子だけでなく女子においても活動的にゲームに参 加できたのかもしれない.

次に，各速度別の走行距離を算出した。その結 果， 4 対 4, 3 対 3 いずれの場合も中・高強度の 走行距離は $30 \mathrm{~m} \times 20 \mathrm{~m}$ コートが $20 \mathrm{~m} \times 15 \mathrm{~m}$ コー トと比較して有意に高值を示した（図 1 および図
3).このことに関連して, 体力的な視点から子ど もたちがゲームをどのように評価しているかを 検討した。質問紙調査の結果をみると，4対 4 で は，体力面の質問項目 10 （無気的持久力）に対 して肯定的な回答を示した児童の割合は $30 \mathrm{~m} \times$ $20 \mathrm{~m}$ のコートでは $75 \%, 20 \mathrm{~m} \times 15 \mathrm{~m}$ のコートで は $56 \%$ であった（表 1). 3 対 3 では，体力面の 質問項目 9 （無気的パワー）に対して肯定的な回 答を示した児童の割合は $30 \mathrm{~m} \times 20 \mathrm{~m}$ のコートで は $66 \%, 20 \mathrm{~m} \times 15 \mathrm{~m}$ のコートでは $50 \%$ であった (表 2).このことから, 児童は主観的にもコート の広いゲームにおいて, 無気的パワーや無気的持 久力からみた負荷が強くなると評価していたもの と考えられる. 中・高強度の身体活動がどのくら い現れるかが子どもの身体活動に関するガイドラ インにおいても強調されている，体力向上に配慮 した体育授業において，中・高強度の身体活動が 現れる授業展開は，体力が低く日常的に運動量の 少ないと思われる児童にとって特に重要であると いえる．ただし，体育授業における単元のねらい は様々である，例えば，状況判断力の向上を目指 す場合には，ディフェンダーが寄ってくるまでの 時間を短くするために，コートを狭くするとい った工夫の視点も提案されている（山口・齋藤, 2000)。本研究では，ゲームのねらいをパスをつ ないでボールを進めることとした，そのため，ゲ 一ムのねらいとするプレーが数多く出現し，技能 が発揮されることが大切である。このことに関連 して，技術・戦術的な視点から子どもたちがゲー ムをどのように評価しているかを考察した。ゲー ム終了後の質問紙調査の結果をみると, 4 対 4 で は技術・戦術面の質問項目 1（課題達成）に対し て肯定的な回答を示した児童の割合はいずれのゲ ームも $81 \%$ であった（表 1).このことからいず れのゲームにおいても約 8 割の児童は課題（パス をつないでボールを進めること）に対して達成で きたと回答していると判断できる。一方， 3 対 3 では技術・戦術面の質問項目 1（課題達成）に対 して肯定的な回答を示した児童の割合は $30 \mathrm{~m} \times$ $20 \mathrm{~m}$ のコートでは $66 \%, 20 \mathrm{~m} \times 15 \mathrm{~m}$ のコートで は $75 \%$ であった（表 2 )。本研究ではこの理由を 
明示できないが， 3 対 3 の人数に対してコートが 広すぎると味方との距離が長くなり, パスがつな がりにくかったことが推察される.

かつての体力つくりを重視した体育のもとで は，業間体操，全校体育，トレーニングの原理に 基づいた体育実践が盛んに行われた結果, 多くの 体育嫌いを生み出した（高橋，1997）。したがっ て授業をとおして子どもの体力つくりを促してい く場合であっても，児童に好意的に受け止められ たのか否かを検討する必要がある. そのために, 各ゲームの終了後に質問紙調査を心理面の観点か ら検討した（表 1, 表 2). その結果, 心理面の質 問項目 12 「楽しくゲームを行うことはできまし たか」では肯定的な反応を示した児童の割合がい ずれのゲームも 8 割であった.すべての児童がゲ ームの楽しさや喜びに触れることができるように ルールや運動の場を工夫することが求められてい る(文部科学省, 2011). 本研究は運動の場の観 点から工夫するに留まっていることから, 今後は 子どもの実態に応じて, ルールの観点からゲーム を工夫することも必要であろう。

現行の小学校学習指導要領 (平成 29 年度告示) 解説をみると, ボール運動の指導に際しては, プ レイヤーの人数, コートの広さ, 用具, プレイ上 の制限を工夫した簡易化されたゲームを取り入れ ることが明記されている（文部科学省, 2017). これは主として戦術学習の観点から記述されたも のであるが, 体力についてもいえることである. すなわち，限られた授業時間数の中で体力つくり からみた効果をあげるためにはコートの広さや人 数などの条件を工夫する必要がある. 本研究では, 小学校体育サッカーの授業で推奨されている 4 対 4 および 3 対 3 のミニゲーム（日本サッカー協会, 2017）に焦点を当て, コートの広さの相違の観点 から負荷特性を検討することを目的とした。 その 結果, 同じ人数のゲームであってもコートの広さ が大きくなると, 中・高強度の走行距離が多くな ることが示された（図1, 図3). また, コートの 広さによって心理面の関心（質問項目 12）に違 いが現れなかった（表 1, 表2).しかし, コート を広げることによって, 相手が寄ってくるまでの
時間が長くなる (遅く緩やかになる) ことにより， 状況判断力の養成にマイナスになる場合があるこ とが報告されている（山口・齋藤，2000）。この ことから, ねらいに応じて, また子どものレベル に応じてコートの広さを調節する必要があると考 えられる. 一方, 4 対 4 ではゲーム中の総走行距 離と体力テストの合計点との間に有意な正の相関 関係が認められたものの, 3 対 3 ではそのような 関係は見られなかった (図 2, 図 4). 日本サッカ 一協会（2017）は, 運動の苦手な子どもに対して, 大勢の中にまぎらせてしまうことにより，その子 どもに負担をかけないように配慮してしまいがち である点を指摘するとともに，その反対の発想を 推奨している. しかし, このことはこれまで経験 則で語られてきたものであり, 客観的なデータと して示されていない. 本研究の結果は, 4 対 4 の 場合には特定の児童においてゲーム中の関わりが 少なく, 運動量が低下する可能性があるのに対し て, 3 対 3 のゲームではすべての览童がゲームに 関わらざるを得ない状況にあることを客観的に示 すものである. 本研究ではボール運動のサッカー を対象に検討したが, 他のボール運動の授業でも このような工夫をもとに授業が展開されれば，子 どもの体力を高めることができるものと考えられ る. なお，本研究には以下に示すような研究の限 界と今後の課題がある. 実験 1（4 対 4 の場合） と実験 2（3 対 3 の場合）ではそれぞれ別の児童 がゲームを実施したことから厳密に比較検討する ことはできない.また本研究は 1 回の運動に対す る負荷特性を検討した横断的研究であり, 単元を 通しての授業効果を検討する, いわゆる縦断的な 研究ではない. したがって, 今後は工夫したゲー ムを単元全体の中に組み込んだ指導プログラムを 準備し, その効果を検証することが必要である. 本研究はこのような課題を有するが, 小学校体育 サッカーで推奨されている 4 対 4 および 3 対 3 に 着目し, コートの広さの相違によりどのような応 答がみられるのかを明らかにした点で意義がある と考えられる. 


\section{$V$ 要 約}

本研究では, 小学校体育サッカーの授業で推奨 されている 4 対 4 および 3 対 3 のミニゲーム（日 本サッカー協会，2017）に焦点を当て，コートの 広さの相違の観点から体力つくりからみた負荷特 性を小学校高学年を対象に検討することを目的と した。そのために，小学 6 年生の児童 16 名に, コートの広さを変えた 4 対 4 のゲームを実施させ た.また, 別の児童 12 名に, コートの広さを変 えた 3 対 3 のゲームを実施させた。いずれもゲー ム時間は各ゲーム 3 分とした。

ゲーム 1-1：コートの広さ：縦 $30 \mathrm{~m} \times$ 横 $20 \mathrm{~m}$, 人数: 4 対 4

ゲーム 1-2：コートの広さ：縦 $20 \mathrm{~m} \times$ 横 $15 \mathrm{~m}$, 人数: 4 対 4

ゲーム 2-1：コートの広さ：縦 $30 \mathrm{~m} \times$ 横 $20 \mathrm{~m}$, 人数: 3 対 3

ゲーム 2-2：コートの広さ：縦 $20 \mathrm{~m} \times$ 横 $15 \mathrm{~m}$, 人数: 3 対 3

対象児童に GPS を装着させ，ゲーム中の総走 行距離および各速度での走行距離を測定した。 ま た，ゲーム終了後に技術・戦術面，体力面，心理 面に対する質問紙調査を実施した。

本研究の主な結果は以下のとおりである.

(1)ゲーム中の総走行距離（全体）は， $30 \mathrm{~m} \times$ $20 \mathrm{~m}$ のコートが $20 \mathrm{~m} \times 15 \mathrm{~m}$ のコートと比較 して有意に高值を示した。

(2)ゲーム中の中・高強度の走行距離は, $30 \mathrm{~m} \times$ $20 \mathrm{~m}$ のコートが $20 \mathrm{~m} \times 15 \mathrm{~m}$ のコートと比較 して有意に高値を示した。

(3)質問紙調査の結果, 心理面の質問項目 12 「楽 しくゲームを行うことができましたか」にお いて肯定的に回答した児童の割合はいずれの ゲームも 8 割を超えた.

(4) 4 対 4 ではゲーム中の総走行距離と体力テス トの合計点との間に有意な正の相関関係が認 められるが，3 対 3 ではみられなかった。

以上より, 同じ少人数のゲームであってもコー トの広さを大きくすることにより，体力つくりに
対する効果を期待できると考えられる．また本研 究の結果は, 3 対 3 のゲームでは体力の低い児童 であっても運動量・運動強度を確保できることを 示唆するものである.

\section{付記}

本研究のデータは, 文部科学省科学研究費補助 金・基盤研究 C（研究課題番号：19K11628）の 助成を受けて得られたものである.

\section{文 献}

Butte, N. F., K.B. Watson, K. Ridley, I. F. Zakeri, R. G mcmurray, K. A. Pfeiffer, S. E. Crouter, S. D. Herrmann, D. R. Bassett, A. Long, Z. Berhane, S. G. Trost, B. E. Ainsworth, D. Berrigan, and J. E. Fulton. (2018) A youth compendium of physical activities: activity codes and metabolic intensities. Med. Sci. Sports Exerc., 50(2) : 246256.

Cunniffe, B., Proctor, W., Baker, J.S., and Davies, B. (2009) An evaluation of the physiological demands of elite rugby union using global positioning system tracking software. Journal of Strength and Conditioning Research, 23(4): 1195-1203.

土肥照典・加藤謙一・秋本寛次（2004）小学校 6 年生の 体育授業における走り幅跳びの練習効果. 体育学研究, 49(5) : 457-469.

古川拓生（2013）ラグビーコーチングにおける GPS の 活用と可能性. コーチング学研究, 26(2)：187-196.

Hill-Hass, S. V., Dawson, B., Impellizeri, F. M., and Coutts, A. J. (2011) Physiology of small-sided games training in football - A systematic review -. Sports Medicine, 41(3) : 199-220.

加藤謙一 ・関戸康雄・岡崎秀充（2000）小学校 6 年生の 体育授業における疾走能力の練習効果. 体育学研究, 45(4) : 530-542.

Mohr, M., Krustrup, P., and Bangsbo, J. (2003) Match performance of high-standard soccer players with special reference to development of fatigue. J Sports Sci., 21(7): 519-528.

文部科学省（2006）新体力テスト：有意義な活用のため に.ぎょうせい.

文部科学省（2011）小学校体育（運動領域）まるわかり ハンドブック https://www.mext.go.jp/component/a_menu/ sports/detail/_icsFiles/afieldfile/2011/07/06/1308040_11. pdf（参照日 2020 年 8 月 21 日）

文部科学省 (2017) 小学校学習指導要領 (平成 29 年告示) 
解説 体育編. 東洋館出社.

中西健一郎・舘俊樹 - 小澤治夫 - 高橋和子 - 福田哲 - 坂

本慎・徐広孝 (2018) GPS 測定器を活用した中学校

保健体育サッカー授業における運動負荷に関する基礎

研究．スポーツと人間，3(1)：147-152。

中島友樹 - 佐々敬政 - 筒井茂喜 - 後藤幸弘（2017）小学 校高学年児童を対象とした状況判断 能力を高めるバ スケットボールの授業実践事例. スポーツ教育学研究, 37(1) : 19-31.

日本学術会議（2017）子どもの動きの健全な育成をめ ざして一基本的動作が危ない一. http://www.scj.go.jp/ ja/info/kohyo/pdf/kohyo-23-t245-1.pdf（参照日 2020 年 4 月 27 日）

日本サッカー協会 (2017) 小学校体育 全学年対応 新・ サッカー指導の教科書. 東洋館出版社.

日本体育協会（2015）アクティブ・チャイルド・プログ ラム 子どもの心と体を育む楽しいあそび. ベースボ ールマガジン社, pp.31-37.

尾縣貢・高橋健夫・高本恵美・細越淳二・関岡康雄（2001） オーバーハンドスロー能力改善のための学習プログラ 么の作成: 小学校 $2 \cdot 3$ 年生を対象として. 体育学研究, 46(3) : 281-294.

鬼澤陽子・小松崎敏・岡出美則・高橋健夫・齊藤勝史・ 篠田淳志（2007）小学校高学年のアウトナンバーゲー ムを取り入れたバスケットボール授業における状況判 断力の向上. 体育学研究, 52(3) : 289-302.

鬼澤陽子・小松崎敏·吉永武史・岡出美則・高橋健夫 (2008) 小学校 6 年生のバスケットボール授業における 3 対 2 アウトナンバーゲームと 3 対 3 イーブンナンバーゲー ムの比較一ゲーム中の状況判断力及びサポート行動に 着目して。体育学研究, 53(2)：439-462.

鬼澤陽子・小松崎敏・吉永武史・岡出美則・高橋健夫 (2012) バスケットボール 3 対 2 アウトナンバーゲームに执い て学習した状況判断力の 3 対 3 イーブンナンバーゲー ムへの適用可能性 : 小学校高学年を対象とした体育授
業におけるゲームパフォーマンスの分析を通して．体 育学研究, 57(1)：59-69.

スピンドラー：松本光弘・野地照樹訳（2000）サッカー コーチング Book. ベースボールマガジン社.

スポーツ庁（2016）平成 27 年度体力・運動能力調査報 告書.

スポーツ庁（2019）令和元年度全国体力・運動能力, 運動習慣調查. https://www.mext.go.jp/sports/content/ 20191225-spt_sseisaku02-000003330_2.pdf（参照日 2020 年 4 月 16 日）

高橋健夫（1997）体育科の目的・目標論. 竹田清彦・高 橋健夫 - 岡出美則編, 体育科教育学の探求, 大修館書 店, pp18-40.

Tsuda, R., Shinozaki, T., Goto, K., and Takamatsu, K. (2007) Load characteristics of mini games in soccer from the viewpoint of improvement in physical fitness: the effect of differences in court area and the number of players. International Journal of Sport and Health Science, 5: 42-53. 津田龍佑・井上明浩・鈴木宏哉・丸谷泰彦 (2013) ゴー ル型のサッカー授業における体力つくりを企図した指 導プログラムの効果 : コートの広さを工夫したゲーム 教材に着目して。体育学研究, 58(1) : 297-307.

津田龍佑・井上明浩・鈴木宏哉・齊藤一彦（2014）体力 つくりに配慮したゴール型のサッカー授業における指 導プログラムの効果 : コートの広さを工夫した 8 人制 のゲーム教材に着目して. Football Science, Vol.11(1) : 29-38.

山口隆文・齋藤隆（2000）サッカーの練習プログラム. 大修館書店, pp.71-74.

$\left(\begin{array}{l}2020 \text { 年 } 5 \text { 月 } 20 \text { 日受付 } \\ 2020 \text { 年 } 12 \text { 月 } 14 \text { 日受理 }\end{array}\right)$

Advance Publication by J-STAGE Published online 2020/12/26 
資料 14 対 4 のゲーム中の個人データ

\begin{tabular}{|c|c|c|c|c|c|c|c|c|c|c|c|}
\hline & & & & 4 対 $4,30 \mathrm{~m}$ & $\times 20 \mathrm{~m}$ & & & 4 対 $4,20 \mathrm{~m}$ & $\times 15 \mathrm{~m}$ & & \\
\hline 千一 & 番兵 & 性剈 & 計占 (占) & 走行距離 $(\mathrm{m})$ & 各速 & 变の走行趿 & 巨離 (m) & 走行距薙 (m) & 各速 & 度の走行趷 & 巨離 (m) \\
\hline & & & 可然(尔) & 企仃此融 (m) & $0-5.9$ & $6-14.9$ & $15.0-23.0$ & & $0-5.9$ & $6-14.9$ & $15.0-23.0$ \\
\hline A & 1 & $\mathrm{~F}$ & 75 & 228.7 & 123.2 & 83.3 & 22.2 & 187.4 & 117.0 & 70.4 & 0.0 \\
\hline$\ddot{A}$ & 2 & $\mathrm{~F}$ & 73 & 178.7 & 111.7 & 66.9 & 0.0 & 143.8 & 106.9 & 36.9 & 0.0 \\
\hline $\mathrm{A}$ & 3 & $\ddot{M}$ & 65 & 241.9 & 131.5 & 99.9 & 10.5 & 211.9 & 98.2 & 110.3 & 3.4 \\
\hline$\ddot{A}$ & $\dddot{4}$ & $\ddot{M}$ & 56 & 185.2 & 131.0 & 34.2 & $\ddot{0.0}$ & 172.1 & 133.6 & 38.6 & 0.0 \\
\hline $\mathrm{B}$ & 1 & $\mathrm{~F}$ & 75 & 191.0 & 112.4 & 77.6 & 1.0 & 118.0 & 108.9 & 9.1 & 0.0 \\
\hline$\ddot{B}$ & $\dddot{2}$ & $\ddot{M}$ & 61 & 210.1 & 117.1 & 89.3 & 3.7 & 155.8 & 100.1 & 35.7 & 0.0 \\
\hline$\ddot{B}$ & 3 & F & 50 & 118.5 & 113.6 & 4.9 & $\ddot{0} 0$ & 64.9 & 64.9 & 0.0 & 0.0 \\
\hline B & 4 & $\mathrm{M}$ & 48 & 162.7 & 149.9 & 12.9 & 0.0 & 178.5 & 137.9 & 40.6 & 0.0 \\
\hline $\mathrm{C}$ & 1. & $\mathrm{~F}$ & 80 & 292.4 & 113.2 & 132.8 & 46.4 & 233.8 & 122.0 & 97.0 & 14.9 \\
\hline$\ddot{C}$ & $\ddot{2}$ & $\ddot{\mathrm{F}}$ & $\ddot{72}$ & 250.6 & 99.5 & 134.4 & 16.8 & 196.9 & 110.2 & $\ddot{84} 4$ & 2.3 \\
\hline $\mathrm{C}$ & 3 & M & 61 & 268.6 & 94.1 & 174.5 & 0.0 & 180.3 & 119.3 & 61.0 & 0.0 \\
\hline $\mathrm{C}$ & 4 & M & 50 & 246.4 & 95.3 & 151.1 & 0.0 & 179.9 & 148.2 & 31.7 & 0.0 \\
\hline D & 1 & $\mathrm{M}$ & 76 & 274.8 & 107.7 & 123.6 & 43.4 & 259.6 & 124.7 & 120.0 & 14.9 \\
\hline $\mathrm{D}$ & 2 & $\mathrm{~F}$ & 76 & 279.2 & 110.0 & 165.9 & 3.3 & 214.1 & 145.7 & 68.4 & 0.0 \\
\hline D & 3 & $\mathrm{~F}$ & 65 & 274.2 & 109.4 & $\begin{array}{l}\ldots \ldots .5 \\
\ldots \ldots\end{array}$ & 15.3 & 196.7 & 133.3 & 58.1 & 5.3 \\
\hline D & 4 & $\mathrm{M}$ & 53 & 247.5 & 115.2 & 132.4 & 0.0 & 39.2 & 39.2 & 0.0 & 0.0 \\
\hline
\end{tabular}

資料 23 対 3 のゲーム中の個人データ

\begin{tabular}{|c|c|c|c|c|c|c|c|c|c|c|c|}
\hline & & & & 3 対 $3,30 \mathrm{~m} \times 2$ & $0 \mathrm{~m}$ & & & 3 対 $3,20 \mathrm{~m} \times 1$ & $5 \mathrm{~m}$ & & \\
\hline 千一 & & 性品 & 休力合計占(占) & 走行距 & 各速 & 度の走行 & 炬離(m) & 走行距㒕 & 各速 & 度の走行趿 & 炬離(m) \\
\hline 厂 & & 恃乃 & 门体)丁口訂点(㿝) & 企1丁此嚯(m & $0-5.9$ & $6-14.9$ & $15.0-23.0$ & 企1丁此霍( & $0-5.9$ & $6-14.9$ & $15.0-23.0$ \\
\hline a & 1 & $\mathrm{~F}$ & 75 & 247.7 & 104.5 & 140.4 & 2.8 & 147.9 & 141.3 & 6.6 & 0.0 \\
\hline$\ddot{a}$ & $\ddot{2}$ & $\ddot{F}$ & $\ddot{71}$ & 265.6 & 103.0 & 161.1 & 1.5 & 178.8 & 132.4 & $\ddot{43.6}$ & 2.8 \\
\hline$\ddot{a}$ & 3 & M & 67 & 208.8 & 124.2 & 80.5 & $\ddot{4} .1$ & 197.9 & 128.3 & 69.6 & 0.0 \\
\hline $\mathrm{b}$ & 1 & $\mathrm{~F}$ & 73 & 279.3 & 102.5 & 128.7 & 48.1 & 221.9 & 122.8 & 79.7 & 19.4 \\
\hline$\ddot{b}$ & $\ddot{2}$ & $\ddot{\mathrm{F}}$ & 62 & 193.0 & 127.5 & 65.5 & 0.0 & 123.8 & 121.2 & 2.6 & 0.0 \\
\hline $\mathrm{b}$ & 3 & $\mathrm{M}$ & 60 & 280.5 & 99.0 & 162.6 & 19.0 & 197.3 & 126.7 & 63.0 & 7.6 \\
\hline $\mathrm{c}$ & 1 & $\mathrm{M}$ & 79 & 228.5 & 128.5 & 81.9 & 18.2 & 211.8 & 113.8 & 91.9 & 6.1 \\
\hline $\mathrm{c}$ & 2 & $\mathrm{M}$ & 77 & 204.8 & 109.4 & 80.8 & 14.6 & 179.3 & 113.0 & 46.5 & 19.8 \\
\hline $\mathrm{c}$ & 3 & $\mathrm{~F}$ & 62 & 146.0 & 109.5 & 36.5 & 0.0 & 109.6 & 98.3 & 11.3 & 0.0 \\
\hline $\mathrm{d}$ & 1 & $\mathrm{~F}$ & 76 & 217.7 & 121.2 & 96.6 & 0.0 & 190.4 & 98.8 & 84.3 & 7.4 \\
\hline d & 2 & $\mathrm{M}$ & 70 & 257.9 & 106.3 & 136.9 & 14.7 & 183.1 & 119.7 & 53.5 & 9.9 \\
\hline$\ddot{d}$ & 3 & $\ddot{\mathrm{F}}$ & 62 & 198.1 & 136.1 & 61.9 & 0.0 & 152.9 & 113.0 & 39.9 & 0.0 \\
\hline
\end{tabular}

